\title{
Hvordan skal vi avgjøre om alvorlig sinnslidelse innebærer utilregnelighet? Refleksjoner om lovforslaget i Prop. 154 L (2016-2017)
}

\author{
LINDA GRÖNING*
}

\section{Et etterlengtet lovforslag}

Hvordan strafferettslig utilregnelighet ved psykisk lidelse skal reguleres er et vanskelig og omtvistet spørsmål. Spørsmålet ble nylig utredet av tilregnelighetsutvalget i NOU 2014:10 - Skyldevne, sakkyndighet og samfunnsvern. ${ }^{1}$ Departementets oppfølgningsproposisjon kom rett før sommerferien i Prop. 154 L (2016-2017). ${ }^{2}$

Etter gjeldende regel i straffeloven $₫ 20$ bokstav b) er den som er psykotisk på handlingstiden å anse utilregnelig og dermed fri fra straffansvar. Straffelovens psykosevilkår har medisinsk forankring ved at det vises til tilstander som medisinsk regnes som psykose, men er likevel ikke helt sammenfallende med det medisinske psykosebegrepet. Vilkåret forutsetter at psykosen viser seg på handlingstidspunktet med åpenbare symptomer, slik at en person med en vel-medisinert psykoselidelse (for eksempel schizofreni) vil falle utenfor. Det kreves imidlertid ikke, slik som etter det såkalte blandede prinsipp som praktiseres i mange land, at psykosetilstanden må ha innvirket på gjerningsperson-

* Professor ved Det juridiske fakultet i Bergen, forsker ved Kompetansesenter for sikkerhets-, fengsels- og rettspsykiatri ved Haukeland Universitetssykehus.

1 Utredningen finnes tilgjengelig på https://www.regjeringen.no/no/dokumenter/NOU-2014-10/ id2008986/ (12.12.2017).

2 Prop. 154 L (2016-2017) Proposisjon til Stortinget (forslag til lovvedtak). Endringer i straffeloven og straffeprosessloven mv. (skyldevne, samfunnsvern og sakkyndighet). Proposisjonen finnes tilgjengelig på https://www.regjeringen.no/no/dokumenter/prop.-154-1-20162017/id2557006/ (12.12.2017).

This is an Open-access article distributed under the terms of the Creative Commons Attribution 3.0 Unported License (http://creativecommons.org/licenses/ by/3.0/), permitting all use, distribution, and reproduction in any medium, provided the original work is properly cited. 
ens tanke- eller handleevner på noen bestemt måte, eller at tilstanden har vært årsak til lovbruddet.

Gjeldende regel, og den medisinske modellen den gir uttrykk for, har særlig i etterkant av 22. juli-saken vært gjenstand for utbredt diskusjon og kritikk. Kritikken har gitt seg mange uttrykk. Vanlige innvendinger er at psykosevilkåret ikke gir en adekvat avgrensning av de som bør anses utilregnelige, at det skaper forvirring i praktiseringen av reglene, og gir de sakkyndige for stor innflytelse. Det var i lys av denne kritikken at Tilregnelighetsutvalget ble oppnevnt for (igjen) å se på behovet for endringer i reglene om utilregnelighet. Konklusjonen ble imidlertid at psykosevilkåret og den medisinske modellen for utilregnelighet ved psykisk sykdom skulle beholdes, men mykes opp noe. Det ble foreslått en regel som dels angir en viss rettslig presisering av lovens psykosekriterium, dels angir at også tilstander som er likestilte med psykose skal omfattes. ${ }^{3}$ Videreføringen av psykosevilkåret var dels basert på argumenter om at dette vilkåret utpeker tilstander som typisk bør medføre straffrihet, dels på argumenter om forutberegnelighet. ${ }^{4}$

Som medlem i utvalget ventet jeg i spenning på oppfølgningen fra Justis- og beredskapsdepartementet. Proposisjonen angår et viktig tema og fortjener omtale og diskusjon, ikke minst om hvilke lovendringer som til sist bør komme ut av den.

Jeg vil i det følgende bidra med noen refleksjoner til en slik diskusjon. Mitt fokus vil være på forslaget til en ny regel for utilregnelighet ved psykisk sykdom. Jeg er særlig på dette punktet kritisk til proposisjonen, som jeg ellers synes inneholder mange gode endringsforslag. Min kritiske vurdering til forslaget om utilregnelighetsregel knytter seg først og fremst til at lovforslaget ikke klargjør hvordan og hvorfor psykisk lidelse kobles til strafferettslig utilregnelighet. I stedet bygger forslaget på tanken om at konkretiseringen først skal skje hos domstolene, gjennom bruk av dommerskjønn i utilregnelighetssaker. En slik løsning synes jeg svikter i ivaretagelsen av grunnleggende rettsprinsipp om maktfordeling, likebehandling og vern mot vilkårlig maktbruk. Jeg skal klargjøre dette, og andre aspekter av min kritikk, i det følgende.

\section{Forslaget om ny utilregnelighetsregel i korthet}

I proposisjonen foreslås en ny utforming av regelen i strl. $\$ 20$ om utilregnelighetsgrunnene, under den nye overskriften skyldevne - som da erstatter utilregnelighet. Denne

3 Regelen lyder i sin helhet: 'Den som retten anser for å ha vært psykotisk på handlingstiden eller i en tilstand som med hensyn til sviktende funksjonsevne, forstyrret tenkning og for øvrig manglende evne til å forstå sitt forhold til omverdenen, må likestilles med å være psykotisk, er ikke strafferettslig ansvarlig. Se NOU 2014:10 Skyldevne, sakkyndighet og samfunnsvern særlig avsnitt 8.9 for en forklaring av regelen.

$4 \quad$ Se ibid avsnitt 6.4.2 og 8.3. 
overskriften understreker helt riktig hva utilregnelighetsspørsmålet handler om, nemlig hvem som skal anses å ha evne til strafferettslig ansvarlig handlemåte - til å voere skyldig.

I tillegg til alder er det en rekke tilstander som kan føre til strafferettslig utilregnelighet, herunder sinnslidelser, utviklingshemning og bevissthetsforstyrrelser. Når det gjelder regelen om utilregnelighet ved psykisk sykdom foreslås det at psykosevilkåret forlates. I stedet foreslås en ny regel med et grunnvilkår om at den som på handlingstidspunktet er utilregnelig på grunn av alvorlig sinnslidelse ikke er strafferettslig ansvarlig. I likhet med den danske regelen for utilregnelighet ved psykisk sykdom brukes uttrykket utilregnelig i loven. Etter forslaget defineres altså i utgangspunktet utilregnelighet med bruk av et vilkår om utilregnelighet. Gjennom slik å kreve (og anta) sammenheng mellom en tilstand av alvorlig sinnslidelse og utilregnelighet, gir regelen tydelig en mer selvstendig betydning og rom for dommerskjønn. ${ }^{5}$

Dette rommet for skjønn er imidlertid tenkt å være noe avgrenset, gjennom kriterier som presiserer regelens innhold i bestemmelsens tredje ledd. Her går det frem at det ved utilregnelighetsvurderingen skal legges vekt på graden av svikt $i$ virkelighetsforståelse og funksjonsevne. I denne vurderingen vil det ikke kreves bevis for tilstandens innvirkning på den aktuelle handlingen, men det avgjørende vil være 'hvorvidt tilstanden på handlingstidspunktet er så alvorlig at den har en innvirkning på forståelsen av omverdenen.' ${ }^{6}$ Slik Randi Rosenqvist mange ganger treffende har sagt: Det avgjørende er at lovbryteren var utilregnelig mens han foretok lovbruddet, ikke at han begikk lovbruddet fordi han var utilregnelig. ${ }^{7}$ I så måte kan også den nye foreslåtte bestemmelsen beskrives som et slags modifisert medisinsk prinsipp. Samtidig går den foreslåtte bestemmelsen betydelig lenger enn forslaget i NOU 2014:10 ved at psykosevilkåret og dets klare medisinske referanse forlates. Den nye regelen overlater betydelig mer av avgrensingen av utilregnelighet ved psykisk sykdom til rettens skjønn. Forslaget legger samtidig til grunn, i likhet med hva som er tilfelle etter gjeldende rett så vel som forslaget i NOU 2014:10, at det er en meget snever gruppe av psykisk syke lovbrytere som skal kunne anses utilregnelige.

\section{Kritisk vurdering}

\subsection{Psykosevilkåret forlates til fordel for en ny retning for bedømmelse av skyld}

Etter departementets forslag forlates altså psykosevilkåret til fordel for 'en ny retning for bedømmelsen av skyld' som bygger på at retten får et større rom for skjønn. ${ }^{8} \AA$ A fjerne

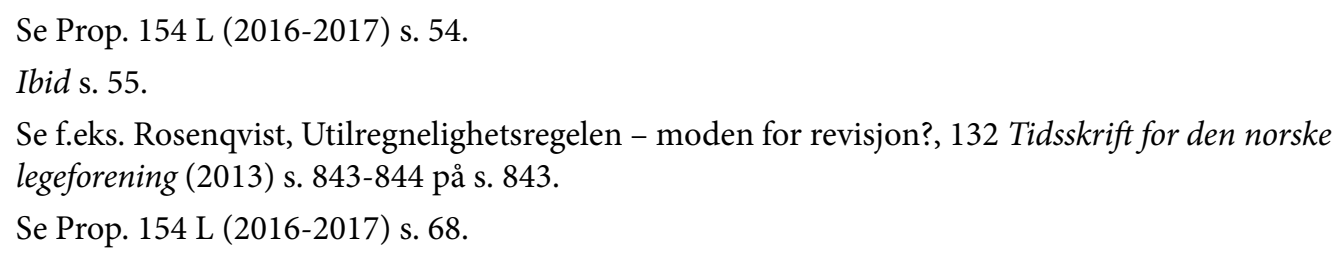


psykosevilkåret fra lovteksten har i seg selv visse gode grunner for seg. Selv om dette vilkåret i stor grad fanger kjernen av strafferettens utilregnelighetsbegrep, er der også problemer knytt til det. Når loven tar sitt utgangspunkt i det medisinske psykosebegrepet, er det psykosetilstanden, og ikke psykoselidelsen, som er det sentrale. For at en tilstand skal falle inn under lovens vilkår kreves det etter $\$ 20$ at gjerningspersonen var psykotisk på handlingstidspunktet. Det betyr som nevnt innledningsvis at hvis en person med en schizofrenidiagnose på grunn av behandling fungerer godt og ikke er psykotisk på handlingstidspunktet, så er vedkommende tilregnelig og ansvarlig for sine handlinger. Det er i dag også den dominerende rettslige oppfatningen at en gjerningsperson må være i en tilstrekkelig inngripende sykdomstilstand for å gå fri fra ansvar - slik at det ligger et krav om symptomtyngde i psykosevilkåret. ${ }^{9}$ Denne distinksjonen mellom det å ha en diagnose på en psykoselidelse og det å være (tilstrekkelig) psykotisk slik som straffeloven krever, virker imidlertid å ha gitt opphav til en del forvirring i samhandlingen mellom psykiatri og juss. ${ }^{10}$ Det var også mot denne bakgrunnen at det i NOU 2014:10 ble foreslått at psykosevilkåret blir presisert slik at det blir klart at det bare er den som på handlingstiden hadde markante psykotiske symptomer som skal gå fri for ansvar.

En annen kritikk som kom opp i etterkant av utvalgets arbeid, handler om hva psykosevilkåret kommuniserer om de med psykiske sykdommer. ${ }^{11} \mathrm{I}$ høringssvarene på NOU 2014:10 har mange instanser gitt uttrykk for at bruken av dette uttrykket er svært problematisk fordi det innebærer en stigmatisering og i verste fall en diskrimineringsproblematikk. ${ }^{12}$ Selv om denne kritikken mange ganger kan møtes med rettslige argumenter, ${ }^{13}$ synes jeg at strafferetten som et demokratisk prosjekt helst bør definere utilregnelighet i allmennspråklige og ikke i medisinske termer. Generelt bør strafferetten være bevisst sin funksjon i å skape og befeste samfunnsoppfatninger, og bør i så liten grad som mulig bidra til ugrunnede negative holdninger mot visse grupper i befolkningen.

9

Se NOU 2014:10 avsnitt 6.4 og Prop. 154 L (2016-2017) avsnitt 4.3. Se også nyhetsbrev fra Den rettsmedisinske kommisjons psykiatriske gruppe, nr. 11, mai 2004.

$10 \quad$ Se f.eks. Rosenqvist (2013) s. 843.

11 For en drøftelse av denne problematikken, se Gröning, Er de norske utilregnelighetsreglene i strid med rettsfølelsen? i Rettsfølelsen i strafferettssystemet - perspektiver fra teori og praksis, red. Frøseth, Gröning og Wandall (Gyldendal 2016) s 157-161.

12 Se for eksempel Høringssvar fra ICJ-Norge - Den internasjonale juristkommisjon, norsk avdeling, Mental helse, Mental helse ungdom, WSO og Stål Bjørkly og Pål Grøndahl ved kompetansesenter for sikkerhet, fengsel- og rettspsykiatri. For et innlegg om diskrimineringsproblematikken knytt til utilregnelighetsreglene, se Lund, Strafferettslig diskriminering - Særlovgivningen rundt utilregnelighet må avvikles, også innenfor strafferetten, Klassekampen, nyhetsklipp, 04.01.2012.

13 Se NOU 2014:10 avsnitt 8.7 og Prop. 154 L (2016-2017) avsnitt 4.6. 
Å fjerne psykosevilkåret kan slik sett medføre positive endringer. Da jeg satt i utvalget var jeg også noe i tvil om dette vilkåret burde videreføres. ${ }^{14}$ Selv om jeg så ulemper med å beholde psykosevilkåret, var jeg imidlertid usikker på hvordan vi kunne utforme et bedre alternativ som fortsatt var presist nok.

Det store problemet med det nye lovforslaget er også akkurat mangelen på et godt alternativ. I stedet for å binde utilregnelighetsvurderingen til et nokså konkret vilkår, åpner denne vurderingen nå for (alt for) stort rettslig skjønn. Etter det nye forslaget skal retten nå foreta en skjønnsmessig helhetsvurdering av hvorvidt en gjerningsperson var utilregnelig på grunn av en alvorlig sinnslidelse, der det skal legges vekt på graden av svikt $i$ virkelighetsforståelse og funksjonsevne. Det betones at spørsmålet om utilregnelighet er et rettslig, og ikke medisinsk, spørsmål som må avgjøres på grunnlag av rettsanvendelse. I stedet for at de sakkyndige skal kunne utøve 'domsmyndighet' i den enkelte sak, skal Høyesterett utvikle standarder for hvilke tilstander og hvilken symptombelastning som innebærer utilregnelighet.

Det er opplagt en oppgave for domstolene, og ikke for de sakkyndige, å sikre en konsistent rettspraksis gjennom anvendelse og tolkning av utilregnelighetsreglene i konkrete saker. Samtidig kan ikke selve definisjonen av strafferettens utilregnelighetsnorm i for stor grad overlates til domstolene. I stedet bør lovgiver legge klare premisser for hvordan utilregnelighetsregelen skal forstås. At dette er en lovgiveroppgave følger allerede av grunnleggende prinsipp om maktfordeling, likebehandling og vern mot vilkårlig maktbruk, ${ }^{15}$ og støttes av effektivitetshensyn. Etter min mening svikter den foreslåtte regelen når det gjelder å gi slike klare premisser for utilregnelighetsvurderingen. De vilkår som regelen inneholder er på ulike måter problematiske og uklare, og åpner for stor usikkerhet om hvem som kan holdes ansvarlig og ikke, og på hvilke grunnlag.

\subsection{Hva er alvorlig sinnslidelse?}

Etter den foreslåtte regelen er grunnvilkåret for utilregnelighet at gjerningspersonen hadde en alvorlig sinnslidelse på handlingstidspunktet. Et vilkår om alvorlig sinnslidelse er allerede brukt i psykisk helsevernloven som hovedvilkår for anvendelse av sivilrettslig tvungent psykisk helsevern. ${ }^{16}$ I denne konteksten er vilkåret forstått som et rent rettslig vilkår som ikke tilsvarer noen medisinsk diagnose. Det omfatter særlig psykosetilstander,

14 Se for en viss reservasjon mot psykosevilkåret i Gröning, Tilregnelighet og utilregnelighet: begreper og regler, vedlegg til NOU 2014:10, Skyldevne, Sakkyndighet og samfunnsvern s. 404428, i avsnitt 10.1 .

15 For en beskrivelse av hvordan maktfordelingsprinsippet blitt utviklet i norsk konstitusjonell rett, og blitt koblet til vern mot vilkårlig maktbruk, se Holmøyvik, Maktfordeling og 1814 (Fagbokforlaget 2012) s. 53-102.

16 Se lov 1999-07-02-62 om etablering og gjennomføring av psykisk helsevern (psykisk helsevernloven) $\$ 3-3$. 
men også andre tilstander kan kvalifisere for tvangsinnleggelse hvis de etter en helhetsvurdering anses alvorlige nok. ${ }^{17}$ Vilkåret treffer dermed videre enn psykosevilkåret i den någjeldende strl. $\$ 20$ bokstav b. Etter departementets mening er en slik utvidelse av det mulige anvendelsesområdet av strafferettens utilregnelighetsregel adekvat. Departementet mener også at bruken av vilkåret alvorlig sinnslidelse gir en bedre løsning enn utvalgets forslag om å omfatte psykose og likestilte tilstander. ${ }^{18}$

Det er jeg veldig i tvil om. Jeg er også veldig i tvil om vilkåret om alvorlig sinnslidelse er bedre enn någjeldende psykosevilkår. Problemet er at det ser ut som om vilkåret skal gis en noe annen betydning i strafferetten enn det har i sivilretten. Departementet nevner eksempelvis spiseforstyrrelser og personlighetsforstyrrelser som tilstander som nok vil falle utenfor den strafferettslige regelen men som i visse tilfeller kan kvalifisere for sivilrettslig tvangsinnleggelse. Departementet sier at:

En fullstendig overlapping $i$ anvendelsesområde er imidlertid uansett ikke hensiktsmessig eller nødvendig når begrepet «alvorlig sinnslidelse» benyttes $i$ lovregler som har helt forskjellige siktemål; det ene som hjemmel for anvendelse av tvangsfullmakter, det andre som grunnlag for straffrihet. Dersom grensene for utilregnelighet trekkes opp i ordlyden for øvrig og i proposisjonen, er det ikke noe i veien for å benytte samme begrep som utgangsvilkår [skal nok voere inngangsvilkår] også i straffeloven. ${ }^{19}$

Disse grensene er, slik jeg leser proposisjonen, ikke særlig tydelige. Problemet er at det ikke er tale om samme begrep, men kun om samme uttrykk - 'alvorlig sinnslidelse' - som nå skal gis to ulike rettslige betydninger. Jeg er redd for at departementet her erstatter den forvirringen som råder rundt psykosevilkåret med en enda større forvirring omkring distinksjonen mellom alvorlig sinnslidelse i strafferetten og i sivilretten. I tillegg lurer jeg på om ikke bruken av termen 'alvorlig sinnslidelse' i straffelovgivningen vil kunne oppfattes som like stigmatiserende som termen 'psykotisk'. Alvorlig sinnslidelse er som rettslig vilkår innarbeidet og assosiert med tvungent psykisk helsevern etter psykisk helsevernloven. Hvis dette vilkåret skal brukes også i en strafferettslig kontekst så er risikoen at det vil kommunisere en uheldig kobling mellom alvorlig psykisk sykdom og kriminell adferd.

\subsection{Hva er utilregnelighet?}

Vilkåret om alvorlig sinnslidelse er som det har fremgått kun et inngangsvilkår som avgrenser de tilstander som kan komme på tale for utilregnelighet. Det kreves etter andre ledd også som tilleggsvilkår at lovbryteren er utilregnelig på grunn av sinnslidelsen.

\footnotetext{
$17 \quad$ Ot.prp. nr. 11 (1998-1999) s. 154.

18 Prop. 154 L (2016-2017) s. 66-68.

$19 \quad$ Ibid s. 67.
} 
Dette tilleggsvilkåret er det mest problematiske med den foreslåtte regelen. Når termen 'utilregnelighet' slik tas i bruk som et kriterium i lovteksten, vil forståelsen av hva det er å være utilregnelig bli avgjørende for beslutninger om straffansvar og straff. Det er da grunnleggende at det gis en (rettslig) avklaring av hva det til sist vil si å være utilregnelig, og hvordan psykisk sykdom er relevant som utilregnelighetsgrunn.

Proposisjonen gir ikke noen slik avklaring. Gjennom vage referanser til klassiske filosofiske og strafferettsteoretiske begreper antydes det hvordan utilregnelighet forstås. I forbindelse med drøftelsen omkring valg av prinsipp, sies det for eksempel at begrunnelsen for 'psykotisk' som kriterium i et medisinsk prinsipp eksempelvis kan være at en slik alvorlig tilstand anses å innebære at evner til forståelse og handlingskontroll mangler. ${ }^{20}$ Videre sies det:

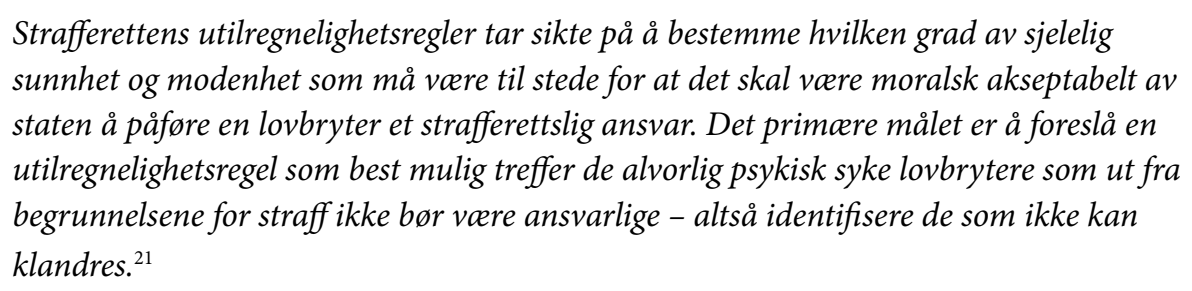

Denne forankringen i klanderhensynet er etter mitt syn adekvat, men hva betyr den mer konkret?

Muligens kan proposisjonen leses slik at de momenter som skal tillegges vekt i utilregnelighetsvurderingen, om svikt i virkelighetsforståelse og funksjonssvikt, også gir en forklaring på hva utilregnelighet handler om. Departementet understreker nemlig at 'det er de helsemessige forhold som er avgjørende ved vurderingen av om lovbryteren er utilregnelig, herunder symptomenes styrkegrad på handlingstidspunktet. ${ }^{22} \mathrm{Og}$ i sammenfatningen heter det: 'Det presiseres nærmere både i ordlyden og i forarbeidene hvilke karakteristiske trekk en har for øye, for å unngå at personer med for eksempel dyssosial personlighetsforstyrrelse (tidligere kalt psykopati) faller innenfor. ${ }^{23}$ Men hvis utilregnelighet skal forstås i forhold til disse momentene om svikt i virkelighetsforståelse og funksjonssvikt, betyr ikke det da at vi står igjen med en medisinsk forklaringsmodell for utilregnelighet? Og hva skal vi da med termen 'utilregnelighet' i lovteksten? Jeg synes ikke et slikt abstrakt og vagt vilkår har noe å gjøre i en regel om straffansvar. Det åpner for usikkerhet, vilkårlighet og ulikebehandling i strafferetten.

$\begin{array}{ll}20 & \text { Ibid s. } 19 . \\ 21 & \text { Ibid s. } 53 . \\ 22 & \text { Ibid s. } 69 . \\ 23 & \text { Ibid s. } 13 .\end{array}$ 


\subsection{Hvilke svikter har betydning for avgjørelsen?}

Uansett hvordan vilkåret om utilregnelighet skal forstås, er dommerens skjønn ikke helt ubegrenset. I tredje ledd i den foreslåtte regelen går det fram at det ved utilregnelighetsvurderingen skal legges vekt på graden av svikt $i$ virkelighetsforståelse og funksjonsevne. Disse momentene er tenkt å presisere at det er de svært symptomtunge tilstandene som bør være gjenstand for utilregnelighet.

I forhold til momentet om 'svikt i virkelighetsforståelse' er det sentrale at det foreligger en grunnleggende realitetsbrist eller mangelfull virkelighetsforståelse. Personen mangler evne til å analysere totalsituasjonen på handlingstidspunktet. Utilregnelighet kan også knyttes til nedsatt funksjonsevne, som da forstås som å omfatte dagligdags, sosial og kognitiv funksjon (tenking, læring, oppmerksomhet, hukommelse, problemløsing, avgjørelser, resonnering, språk og kommunikasjon). ${ }^{24}$

Hvordan disse momentene mer konkret skal forstås og vektlegges i den helhetsvurdering domstolen må gjøre, er imidlertid ikke klart. Realitetsbrist og kognitiv svikt fremstår som det sentrale, slik det også er etter gjeldende rett. Samtidig åpner departementet for at en person kan straffes selv om vedkommende har slike svikter, hvis funksjonsevnen anses god nok: 'Det behøver således ikke å være nok å ha en vrangforestilling. Det kan være vanskelig for allmennheten å akseptere at en person som er relativt velfungerende og i stand til å planlegge og gjennomføre kompliserte lovbrudd, ikke straffes.' Funksjonssvikt skal derfor være et moment som vektlegges i helhetsvurderingen av om tilstanden oppfyller utilregnelighetsnormen. Og hvis funksjonssvikten er veldig stor, åpner departementet for at en person kan anses utilregnelig selv om vedkommende ikke har noen realitetsbrist. ${ }^{25}$

Proposisjonen inneholder ikke noen nærmere forklaring på hvordan realitetsbrist og funksjonssvikt skal forstås og hvordan disse sviktene kan knyttes til ulike psykiske lidelser eller symptomer. Hvordan er for eksempel relasjonen mellom positive psykotiske symptomer, som ofte vektlegges i praksis, og (en tilstrekkelig grad av) realitetsbrist? Og hvordan skal kognitiv svikt forstås i denne sammenhengen; hvilke typer av kognitiv svikt har betydning, hvordan og hvorfor? Når departementet for eksempel, slik som gjengitt ovenfor, antyder at evnen til å planlegge og gjennomføre kompliserte lovbrudd taler mot utilregnelighet, hva sier det mer konkret om utilregnelighetsnormens innhold?

Det er etter departementets syn retten som på etisk og normativt grunnlag selvstendig skal konkludere i utilregnelighetsspørsmålet. Etter departementets forslag bør det avgjørende være om det i betraktning av sinnslidelsens karakter og styrke fremstår som

$\begin{array}{ll}24 & \text { Ibid s. } 69 . \\ 25 & \text { Ibid s. } 69 .\end{array}$ 
rettferdig å holde lovbryteren strafferettslig ansvarlig for lovbruddet. ${ }^{26}$ Grensen for utilregnelighet må således til sist trekkes på grunnlag av rettferdighetsbetraktninger. Når utilregnelighetsvurderingen slik som nå er tilfellet, kobles til faktiske antagelser om psykiske svikter, må samtidig dommeren ha et tilstrekkelig kunnskapsgrunnlag til å gi de rettslige vilkårene et adekvat innhold. Jeg er i tvil om dommeren vil ha det grunnlaget etter det forslag som proposisjonen gir. I lys av manglende rettslig konkretisering, må nok utilregnelighetsnormen til sist likevel konkretiseres gjennom de sakkyndiges bidrag til rettsanvendelsen. Jeg er redd for at det vil ha uheldige konsekvenser også i forhold til en konsekvent og effektiv håndtering av strafferettslige utilregnelighetssaker.

\section{Noen forhåpninger til prosessen fremover}

Det erkjennes i proposisjonen at: 'Det er utfordrende å utforme regler om utilregnelighet som skal være både vitenskapelig oppdatert, praktisk anvendelige for rettens aktører og forsvarlige sett hen til krav til likebehandling og tiltaltes rettssikkerhet.' ${ }^{27}$ Det er det. Et grunnkrav er likevel at en regel om utilregnelighet inneholder tilstrekkelig klare standarder for hvem som kan holdes ansvarlig og ikke, og slik sett gir vern mot vilkårlig maktbruk. For å ivareta maktfordelingshensyn og vern mot vilkårlig maktbruk bør det primært være en ambisjon for lovgiver å klarlegge strafferettens utilregnelighetsnorm gjennom å utforme klare og velbegrunnede regler. Reglene må kunne begrunnes så vel $\mathrm{i}$ relasjon til de filosofiske premisser om straffansvar og utilregnelighet, som i relasjon til de faktiske premisser om psykisk sykdom som reglene bygger på eller involverer. Det er av stor vekt at lovgiver klarlegger hvilke disse premissene er og bringer inn kunnskap om hvordan individer kan bli påvirket av ulike sykdomstilstander. I stedet for en ny retning mot et større rom for dommerskjønn i utilregnelighetssaker, ønsker jeg meg altså en lovgivning med klare og kunnskapsmessig underbygde vilkår for utilregnelighet ved psykisk sykdom. Mer konkret ønsker jeg at vilkåret utilregnelighet ikke kommer med i den lovteksten som vedtas. Å bruke et så uklart vilkår i en utilregnelighetsregel er å kompromisse for mye grunnkravene om maktfordeling, likebehandling og vern mot vilkårlighet. Jeg håper også at vilkåret om 'alvorlig sinnslidelse' byttes ut mot et mer adekvat, og gjerne allmennspråklig, vilkår som kommuniserer at man må være i en meget inngripende mental avvikstilstand for å være utilregnelig.

$26 \quad$ Ibid s. 69.

$27 \quad$ Ibid s. 53. 